similar authorities or with larger neighbours. Coordinated or co-operative buying is, however, of much reduced value if it is not preceded or accom. panied by a fair measure of standardisation and simplification whereby unnecessary variations of type, size and quality can be eliminated. Already the County Councils of Kent, London and the West Riding of Yorkshire have adopted complete centralisation of the buying functions in a supplies department which is independent of other departments ; while the City Councils of Birmingham, Liverpool and Manchester have partially centralised the buying functions in those departments which are the largest users of the particular commodity. Manchester City Council saved $£ 17,000$ in $1933-34$ by determining the best grade of fuel for the heating apparatus at its institutions (thereby halving the number of grades in use), and buying its fuel in bulk and by specification. The Committee strongly emphasises the point that bulk purchase if it is accompanied by standardisation and simplification enables better goods to be bought with less money, but that bulk purchase cannot be operated with maximum success unless the requirements of the buying unit are large enough to command largescale buyers' terms and to employ experienced staff.

\section{Influence of Industrialism on Mortality in Japan}

IN a recent report of the Institute of the Science of Labour, Kurasiki, Japan (No. 29 : (1) Sex-Ratio in the Population of Japan Proper ; (2) The Influence of Industrialism upon the Mortality of Young People and Adults. By Dr. Sinzi Katuki. Pp. 30. Kurasiki : Institute for Science of Labour, 1935. 60 sen), Dr. Sinzi Katuki writing on the influence of industrialism upon the mortality of young people and adults shows that there is in Japan a close correlation between the female death rate in the age group 15-44 years and the rate of migration from the mural to the industrial areas. The death rate among women workers exceeds that of males in every industry except mining. Dr. Katuki concludes that these facts suggest the grave responsibility of industry for the heavy death rate of Japanese girls and young women, since in Europe and America, although employment of women is extensive, the female death rates are much lower than in Japan, absolutely and relatively to the male death rates. It would therefore seem that the high death rate of Japanese women in this age group is the result not of industrial labour in itself but of the bad conditions under which it is carried on and the insufficient protection of female workers. Recent statisties show a remarkable increase in the industrial occupations of women in Japan. Whereas formerly the great majority of women engaged in industrial employment regarded it merely as preparatory to marriage or only as a subsidiary means of subsistence, it has now frequently become their permanent and essential means of livelihood.

\section{Synchronisation of Radio Stations}

THE effect produced when a wireless set receives two different programmes on the same wave-length, although the stations may be widely apart, is sometimes called 'radio hash' in the United States. The
Federal Communications Commission spaces two stations producing the same wave-length as widely apart as possible, but according to a report issued by Science Service, Washington, D.C., the whole country is spotted with these 'hash' or interference areas. In the June number of Electronics, the editor of which, Dr. C. H. Caldwell, was formerly a radio commissioner, a method of synchronising several stations on a given wave-length is described and thus space could be saved in the broadcasting spectrum. If the plan were carried out, no less than 1,527 radio stations could be constantly working in the present 106 channels. If all the stations, on a great nationwide 'chain programme', broadcast only on three adjoining channels, 750, 760 and 770 kilocycles, for example, then it is only necessary to turn on one of these to get the corresponding programme. If one turns to other wave-lengths, then other chain programmes are obtained. In addition, low-powered stations, one kilowatt, for example, could be working -twelve to a broadcast channel--throughout the country. These programmes would be sharply differentiated from the 'chains'. Ten channels would be allotted to Canada, Mexico and Cuba, all of whom are asking for more space on the ether. For the American farmers there would be seven channels for superstations up to 2,000 kilowatts, so that every farmer, however remote, could hear. The 1,500 new stations could be heard with less interference than the few hundreds they would displace.

\section{Express Highways in Germany}

Good progress is being made in the construction of express highways (autobahnen) in Germany. An article in Roads and Streets gives an illustrated description of some of these highways and incidentally gives a photograph of part of an old Germanic plank road, built about 1000 B.c. and excavated a year ago at Bremen. The first 1,000 miles of the express highway has been completed. Most of it consists of a lawn strip 15 feet wide bordered by traffic lanes 25 feet wide on each side, the sides of the whole road having 'shoulders' sloping upwards. Trees and shrubbery are planted on the centre strip and on the shoulders. The shrubbery in the centre strip protects the driver largely from the glaring headlights of cars travelling in the opposite direction. Densely wooded areas are relieved at intervals by small clearings giving views of distant landscapes. There are no crossings, viaducts or subways being provided so as to permit continuous and fast travel. Twelve of the German universities have laboratories for testing road building material. At Braunschweig there is a test track about 1,000 feet in diameter where tests are carried out on different types of surfaces under traffic conditions. The effects of the velocities of the vehicles on different types of tyres and the abrasion of the roads are all studied practically. The testing of materials for the eastern section of Germany, which is separated from the rest of Germany by the Polish Corridor, is done in the Free City of Danzig. It is hoped that the political diffieulties which this Corridor will present to through traffic will soon be overcome. 